\title{
Relationship of Servant Leadership and Employee Loyalty: The Mediating Role of Employee Satisfaction
}

\author{
Donghong Ding ${ }^{1}$, Haiyan Lu' ${ }^{1}$, Yi Song ${ }^{2}$, Qing Lu ${ }^{3}$ \\ ${ }^{1}$ School of Management, University of Science and Technology, Hefei, China; ${ }^{2}$ School of Humannities and Social Science, Univer- \\ sity of Science and Technology, Hefei, China; ${ }^{3}$ School of Business, Nanjing University, Nanjing, China. \\ Email: qiuwuhaiyan@126.com
}

Received July $4^{\text {th }}, 2012$; revised July $23^{\text {rd }}, 2012$; accepted August $1^{\text {st }}, 2012$

\begin{abstract}
There is a growing concern about the relationship of servant leadership and employee loyalty recent years, but few are focusing on the intervening mechanisms between them. Especially in China, research on such mediating variables is nearly blank. In this paper, we make our attempt on detecting the role in such relationship by empirical studies through 186 samples using the structural equation model (SEM) method, and reach two conclusions: servant leadership is significantly positive correlated with employee loyalty; employee satisfaction is found to play mediating role which occupies $77 \%$ of the total effect between servant leadership and employee loyalty. Our result shows that, to improve employee loyalty, the managers should not only develop their servant leadership style, but also take into consideration the individual needs to improve psychological satisfaction.
\end{abstract}

Keywords: Servant Leadership; Employee Satisfaction; Employee Loyalty; Mediating Role

\section{Introduction}

How to improve employee loyalty is one of today's most difficult problems that troubles business leaders. Several ways are proposed to solve this problem, among which improving style of leadership is a key perspective, for that to some extent, leadership style determines the relationship between leaders and employees [1]. Researches show that employee turnover is closely related with the quality of the relationship. Mulki et al. [2] suggest in through studies of sales staff that, employees choose to leave when they feel their leaders cannot be trusted or feel unsatisfied with them. On the contrary, Brashear's [3] research points out that those leaders who cultivate harmonious relationships by promoting subordinates' career development will efficiently improve their organizational commitment and loyalty. The traditional style of leadership in China is a top-down paternalistic leadership, which demonstrates a superior command-style authoritarian attitude. But in fact, the staff-oriented style of leadership can bring higher employee satisfaction, and thus increase employee loyalty. The core ideas of servant leadership, put forward by western scholars, include such two aspects: first, the main motivation of servant leadership is to serve employees. To these leaders, the individual employee instead of organization's goal is of first importance and employees' needs take precedence over organization's goal or personal purpose [4]. Second, servant leaders' behavior is driven by their integrity. Servant leadership is considered to be consistent with the development of the times and sustainable, and has a positive effect on employee loyalty.

Western scholars have already started a lot of research about the relationship between servant leadership behavior and employee loyalty. Liden et al. [5] find out that, servant leadership helps to create a positive work environment, enhancing employees' sense of belonging and loyalty to the organization. Fernando Jaramillo et al. [4] study 501 full-time sales staff and find that servant leadership behavior helps employees adapt to their company's environment, enhance their organizational commitment, and thus reduce their turnover intention. On the other hand, further studies have pointed out that, servant leadership does not directly encourage employee loyalty. Instead, mediating variables like employee satisfaction enlarges the effect. Therefore, we set servant leadership and employee loyalty as main variables, joined with employee satisfaction as mediating variable, and we research the relationship of the above three empirically. One of our purposes is to further verify the relationship of servant leadership and employee loyalty in the background of China; the other purpose is to find out how 
staff satisfaction acts as a mediating role in the mechanism of this effect. Our work is meaningful for it not only deepens people's understanding and awareness of relevant theory, but also provides guidance to China's management practices.

\section{Related Works and Assumptions}

\subsection{Servant Leadership}

Servant leadership was first proposed in 1977 by Grenleaf. He believes that to be a leader, one should become a servant first and foremost is the service consciousness. His point of view opens a new page in the history of leadership theory, and wins more agreements than transformational leadership and transactional leadership, which have been prevalent in the 20th century, 1970s. Authentic leadership and spiritual leadership lately proposed in 21st century, and once considered to be leading a new trend in a time of change. Presentations of a servant leadership include orient to service, global vision and paying attention to spiritual and moral. Compared with transformational leadership, servant leadership shows the essence of tendency to serve front-line employees. As Barbuto and Wheeler [6] said, servant leadership is to serve staff, but on the contrary, transformational leadership is to motivate staff to achieve organizational goals ultimately. Compared with authentic leadership, Avolio and Gardner [7] point that both of them are aware of the importance of positive moral view, self-perception, selfrestraint and positive image, and both of them concern for staff career development. But different from authentic leadership, spirit is an important source of motivation to servant leaders [8]. The concept of servant leadership is beyond spiritual leadership. Servant leadership behavior is on behalf of the highest form of leader's commitment to staff.

Researchers put forward their own model framework to measure servant leadership. Among the latest researches, Sendjaya et al. [9] proposed a six-dimensional model of servant leadership, they are: voluntary subordination, authentic self, covenantal relationship, responsible morality, transcendent spirituality, transforming influence. Liden [5] proposed a seven-dimensional model consisting empowering, helping subordinates grow and succeed, putting subordinates first, emotional healing, conceptual skills, creating value for the community, and behaving ethically. Eight-dimensional model by Dirk van Dierendonck [10] includes empowerment, humility, standing back, authenticity, forgiveness, courage, accountability, and stewardship. Chunxiao Wang [11] presents an eleven-dimensional model in the content of China that has respect for employees, care for employees, helping subordinates grow and succeed, idea of desire, being amiable and easy of approach, willing to sacrifice, being impartial and honest, pioneering spirit, provide guidance of staff works, social responsibility, and empowering.

\subsection{Servant Leadership and Employee Loyalty}

Employee loyalty originated from customer loyalty, which scholars thought to be the foundation and driving force of a sustainably developing enterprise. But today, people realize that employee loyalty and customer loyalty are of equal importance [11]. The only way that a company maintains customer loyalty is on the base of maintaining employee loyalty. Although many scholars have studied employee loyalty theoretically, there is still no clear definition of employee loyalty up to now [12]. Popular opinions are the following three: behavioral loyalty, attitude loyalty and comprehensive theory. As Bob points out, employee loyalty is reflected in behavior. There are other scholars believe that employee loyalty is actually the attitude of the employees to the community, and thus it should be studied from the employees' cognition, emotion and behavioral tendencies. This paper tends to accept third comprehensive theory, that is, we consider employee loyalty as the unity of the behavior and attitudes. So in our research, we will separate it into two aspects, attitude loyalty and behavior loyalty.

Through a clear picture of the community's goals, servant leadership gives employee a clear understanding of the importance to the entire community, knowing that they are stakeholders to achieve organizational goals, and thus motivate themselves to make sustained effort to achieve goals. Though care, help and respect for employees, it gives them a good psychological experiences and satisfaction and from inside spirit form a sense of belonging to the community. While the leader shows his quality and personal charm, the employees feel their leader trustable and increase their willingness to stay. Numerous studies indicate that servant leadership behavior has a positive influence on employee loyalty. Early in 1986, Dubinsky and Skinner discovered that care for employees can improve their organizational commitment and promote loyalty. The research by Liden [5] shows that another aspect of servant leadership, helping subordinates grow and succeed, has a positive impact on improving employee loyalty. Fernando Jaramillo [4] study 501 full-time sales staff empirically and they conclude that servant leadership behavior first improves employees' organizational adaptation, enhance their organizational commitment, and thereby reducing their turnover intention. Based on the above analysis, we make the following assumption:

H1: Servant leadership behavior has a positive im- 
pact on employee loyalty.

\subsection{Servant Leadership and Employee Satisfaction}

Concerns on employee satisfaction originate in Hoppock's research. He believes that employee satisfaction reflects the employees' both physical and psychological feelings of their working situation. Locke defines employee satisfaction as a pleasant and positive emotional state from work experience. Bass considers employee satisfaction as a happy emotional state produced in the process to realize or improve one's value. Llies and Judge [13] define employee satisfaction as “a person's attitude construction of their job evaluation”. Some other scholars like Robbins, Naiding Yang and Cuixia Huang think that satisfaction is a relative concept so there is no absolute criterion, but mainly due to the gap between personal expectations and the actual achievement. This expectation is composed by various aspects include remuneration and working environment.

In research by Mak [14], Mohamed et al. [15] they point out that employee satisfaction is an important motivating factor in employee performance, and on the relevant literature review we can see leadership style is an important antecedent variable to employee satisfaction. Today, leaders attempt to establish a harmonious relationship between leadership behavior and employee satisfaction. Researches in the past were analyzed using transformational leadership behavior as independent variable, in which transformational leadership is thought to be the leadership style to improve employee satisfaction. For example, Voon [16], Bekele et al. [17] think that transformational leadership plays a positive impact on employee satisfaction. While in the process of practice compared to transformational leadership, the latest servant leadership style pays more attention to the employees' physical and mental development and passes to employees more comfortable psychological experience, which no doubt brings more satisfaction to employees. Jane [18], Laschinger [19], Chang [20] and many other scholars' studies reveal the positive effect of empowerment behavior in servant leadership on employee satisfaction. Jenkins [21] finds in empirical research of the nursing staff that the higher the leader's service tendency is, the more satisfaction it brings to employees. Sunita's [22] study also finds a significant positive influence in employee awareness of servant leadership behavior and employee satisfaction in the background of India. Based on the above analysis, we make the following assumption:

H2: Servant leadership behavior has a positive impact on employee satisfaction.

\subsection{Mediating Role of Employee Satisfaction}

Many scholars have studied the role of employee satisfaction on employee loyalty and conclude that employee satisfaction influence employee loyalty positively [23,24]. Tang Yao et al. [25] analyze from two perspectives by which staff satisfaction promotes employee loyalty: first, reduce perceived risk. Compared to former unsatisfied company or unfamiliar company in the future, perceived risk is relatively low when one chooses to stay in current company. Second, maximize positive emotion. Employees will inevitably bring about a better psychological feeling in a company with more satisfaction, produce feelings of pleasure, and thus work better. Under the above two, employees tend to stay in the company with higher satisfaction. The empirical result in CC Chang et al. [20] also confirms the same conclusion. Some scholars, such as of Alfonso [26], Chee [27], Falkenburg [28], Wagner [29] point out through empirical research that, when employee satisfaction gets low, the turnover intention increases. That is, the decreasing of employee satisfaction has a negative impact on employee loyalty. These works prove the relation between employee satisfaction and employee loyalty from the reversed view. Based on the works above, we make the following assumption:

H3: Employee satisfaction has a positive impact on employee loyalty.

It has been pointed out that the servant leadership behavior is the antecedent of employee satisfaction, and employee satisfaction can reduce employee turnover intention and job-hopping [30]. According to previous studies, servant leadership behavior probably doesn't have a direct impact on employee loyalty, for the reason that created in the process of servant leadership behavior is the attachment and commitment to their immediate superior, rather than their community. According to Becker's argument, there is difference between employees' loyalty to their superior and to the community. Riketta and Van Dick [31] point out that the focuses of employee commitment to the community and employee loyalty are potential outcome variables of the same level. Therefore, some of the mediating variables, such as employee satisfaction, will expand the influence of servant leadership behavior on employee loyalty, while servant leadership behavior itself is not of enough direct impact on employee loyalty. Under the effect of servant leadership behavior, in a community lack of employee satisfaction, the employee loyalty to their superior will beyond the loyalty to the community. On the contrary, if the employee satisfaction is high, they will show their loyalty to the community directly. Chang's empirical study of employees in a servant leadership community [20] has shown that leadership styles like empowering, rewarding 
and teamwork have a positive impact on employee satisfaction, and employee satisfaction in turn promotes employee loyalty. Millissa [32] in his latest work points out that, if there is a high-qualified exchange relationships between employees and supervisors, their satisfaction will increase, which will strengthen employee commitment and willingness to stay in the community. Coupled with high conversion and opportunity cost of changing job, for those employees with high satisfaction, they are more willing to stay in the organization in order to obtain their best state. Between subordinate exchange and employee's intention to leave, employee satisfaction plays a mediating role. Thus we propose the following assumption:

H4: Employee satisfaction plays a mediating role between servant leadership and employee loyalty.

\section{Research Framework}

According to the above literature review about servant leadership, employee satisfaction and employee loyalty, we suggest a research framework shown in Figure 1. This framework not only describes the direct relationship between these three variables, and also can be used to examine the intermediary role of employee satisfaction.

\section{Research Method}

\subsection{Samples}

The research objects of this study are MBA students of the Chinese University of Science and Technology and part of staff in iFLYTEK. This survey distributed 250 paper questionnaires and 212 of them returned. After removing 26 questionnaires with incomplete answers or not replied seriously, we obtain 186 questionnaires with valid response rate of $74.4 \%$. Basic situations of samples are shown in Table 1.

\subsection{Measuring Tool}

According to the Churchill's scale design principles, our questionnaire mainly concerns servant leadership behavior, employee satisfaction and employee loyalty, and has 55 measuring items in total, including: 1) servant leadership. Using the measuring scale made by Chinese schoolars such as Wang Chunxiao in 2009. The original scale includes 11 dimensions (namely respect for employees, care for employees, helping subordinates grow and succeed, idea of desire, being amiable and easy of approach, willing to sacrifice, being impartial and honest, pioneering spirit, provide guidance of staff works, social responsibility, and empowering) and 44 measuring items. We will be using structural equation model in the rest of this paper, and the problem is that too many latent variables

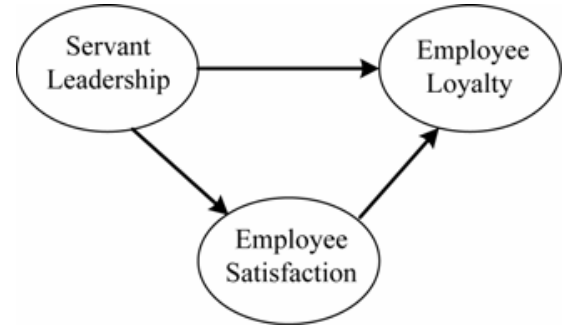

Figure 1. The mediating role of employee satisfaction.

Table 1. Sample information.

\begin{tabular}{|c|c|c|c|}
\hline Variables & \multicolumn{3}{|c|}{ Component of samples } \\
\hline \multirow{2}{*}{ Gender } & Male & 126 & $67.7 \%$ \\
\hline & Female & 60 & $32.3 \%$ \\
\hline \multirow{3}{*}{ Age } & $21-25$ & 62 & $33.3 \%$ \\
\hline & $26-30$ & 104 & $55.9 \%$ \\
\hline & $31-40$ & 20 & $10.8 \%$ \\
\hline \multirow{4}{*}{ Education } & Following college & 2 & $1.1 \%$ \\
\hline & Junior college & 26 & $14.0 \%$ \\
\hline & Undergraduate course & 124 & $66.7 \%$ \\
\hline & Bachelor degree and above & 34 & $18.3 \%$ \\
\hline \multirow{3}{*}{ Position } & Basic level worker & 156 & $83.9 \%$ \\
\hline & Basic management & 26 & $14.0 \%$ \\
\hline & Middle management & 4 & $2.2 \%$ \\
\hline \multirow{4}{*}{$\begin{array}{c}\text { Monthly income } \\
\text { level }\end{array}$} & Below 2000 RMB & 20 & $10.8 \%$ \\
\hline & 2001 - 3000 RMB & 62 & $33.3 \%$ \\
\hline & 3001 - $5000 \mathrm{RMB}$ & 78 & $41.9 \%$ \\
\hline & Above 5000 RMB & 26 & $14.0 \%$ \\
\hline
\end{tabular}

will reduce the fitness of the model, which is of no help to determine the relationship between servant leadership and employee loyalty. In view of this, we pack those correlated dimensions into the following three dimensions: community goals (idea of desire, social responsibility), employee guide (respect for employees, care for employees, helping subordinates grow and succeed, provide guidance of staff works), charm (being amiable and easy of approach, willing to sacrifice, being impartial and honest, pioneering spirit, empowering). The data analysis also shows that this scale is in line with our expectation; 2) employee satisfaction. Mainly based on MSQ scale proposed by Smith, Kendall and Hullin, referred to the questionnaire by Shi Kan et al., and it has 3 measuring items; 3) employee loyalty. Divided into the 2 dimensions of attitude loyalty and behavior loyalty in this study, with reference to the questionnaire designed by Yao Tang [25], and it has 7 measuring items in total. All the 
scales are evaluated by Likert scale of level 1 - 5, where 1 to 5 stand for strongly disagree to strongly agree, respectively.

\subsection{Statistical Method}

In this study, we use SPSS17.0 to perform basic statistical analysis and regression analysis; use AMOS18.0 to perform scale construct validity testing, and structural equation modeling and analysis.

\section{Experimental Results}

\subsection{Reliability and Validity Analysis}

Before data analyzing, we first test the reliability and validity of the questionnaire samples.

Table 2 shows that the Cronbach's $\alpha$ coefficients of servant leadership scale, employee satisfaction scale and employee loyalty scale are $0.92,0.87$ and 0.90 , all above the generally accepted level of 0.80 . It proves that samples are of good reliability to achieve the basic requirements for surveying and research.

Model evaluation indices are shown in Table 3.

According to the data in the table, among those indicators of influencing factors model, CMIN/DF $<3$, RMSEA $<0.08$, GFI, AGFI, IFI, CFI are greater than 0.9. In accordance with the usual standards of management research, CMIN/DF should be between 1 and 3, RMSEA is preferred to be less than 0.08 , but less than 0.1 is acceptable, GFI, AGFI, IFI, CFI should be over 0.9. From the above, the overall fitness of our model is high and it works well, which indicates that the assumption of our theoretical model structure is reasonable. Meanwhile, if we take a look at coefficients in the paths of the model, load of each item in its factor is between 0.78 and 0.97 , all above 0.5 and pass the significance test, which indicates that questionnaire items can fully reflect the factors' contents. To sum up, our questionnaire has good construct validity.

Table 2. Reliability statistics.

\begin{tabular}{cc}
\hline Variables & Cronbach's $\alpha$ \\
\hline Servant leadership & 0.92 \\
Employee satisfaction & 0.87 \\
Employee loyalty & 0.90 \\
\hline
\end{tabular}

Table 3. The fitting effect of the model.

\begin{tabular}{ccccccc}
\hline Index & CMIN/DF & RMSEA & GFI & AGFI & IFI & CFI \\
\hline Value & 2.231 & 0.082 & 0.954 & 0.903 & 0.986 & 0.986 \\
Standard & $1 \sim 3$ & $<0.10$ & $>0.9$ & $>0.9$ & $>0.9$ & $>0.9$ \\
\hline
\end{tabular}

\subsection{Descriptive Statistics and Correlation Analysis of Variables}

Table 4 shows the means, the standard deviations and the correlation coefficients of servant leadership, employee satisfaction and employee loyalty.

Accordingly we can see, servant leadership and employee satisfaction are significantly positively correlated $(\mathrm{r}=0.75, \mathrm{p}<0.01)$; servant leadership and employee loyalty are significantly positively correlated $(r=0.76, p<$ 0.01 ); employee satisfaction and employee loyalty are significantly positively correlated $(\mathrm{r}=0.85, \mathrm{p}<0.01)$.

\subsection{Hypothesis Test in Structural Equation Model}

Figure 2 shows the relationship between the variables of the structural equation model and the path coefficients. Our assumptions of this research are fully supported by data analysis results in this figure. 1) Servant leadership has a significant positive effect on employee satisfaction ( $\beta=0.85, \mathrm{p}<0.001)$, that is, the leader behavior is more inclined to servant, the higher employee satisfaction would be, and vice versa, it would reduce; 2) Servant leadership has a significant positive effect on employee loyalty $(\beta=0.20, \mathrm{p}<0.05)$, that is, the leader behavior is more inclined to servant, the higher employee loyalty, the lower turnover intention and turnover rate would be, and vice versa, turnover intention and turnover rate would grow; 3) Employee satisfaction has a significant positive effect on employee loyalty $(\beta=0.79, \mathrm{p}<0.001)$, that is, the higher employee satisfaction is, the higher employee loyalty, the lower turnover intention and turnover rate would be, and vice versa, turnover intention and turnover rate would grow; 4) Employee satisfaction plays a mediating role between servant leadership and employee loyalty, and as is shown in Table 4, the direct effect is 0.199 , the mediating effect is 0.665 , while the total effect is 0.864 , thus the mediating effect covers $77 \%$ of the total effect $(0.665 / 0.864)$.

\section{Discussions and Suggestions}

Through the way of questionnaire, this article studies the

Table 4. Mean value, Standard deviation, Correlation coefficient $(\mathbf{N}=186)$.

\begin{tabular}{cccccc}
\hline Variables & Mean & $\begin{array}{c}\text { Standard } \\
\text { deviation }\end{array}$ & 1 & 2 & 3 \\
\hline Servant leadership & 3.84 & 0.56 & & \\
Employee satisfaction & 3.90 & 0.72 & $0.75^{* *}$ & & \\
Employee loyalty & 3.73 & 0.74 & $0.76^{* *}$ & $0.85^{* *}$ \\
${ }^{* *} \mathrm{p}<0.01$. & & & &
\end{tabular}




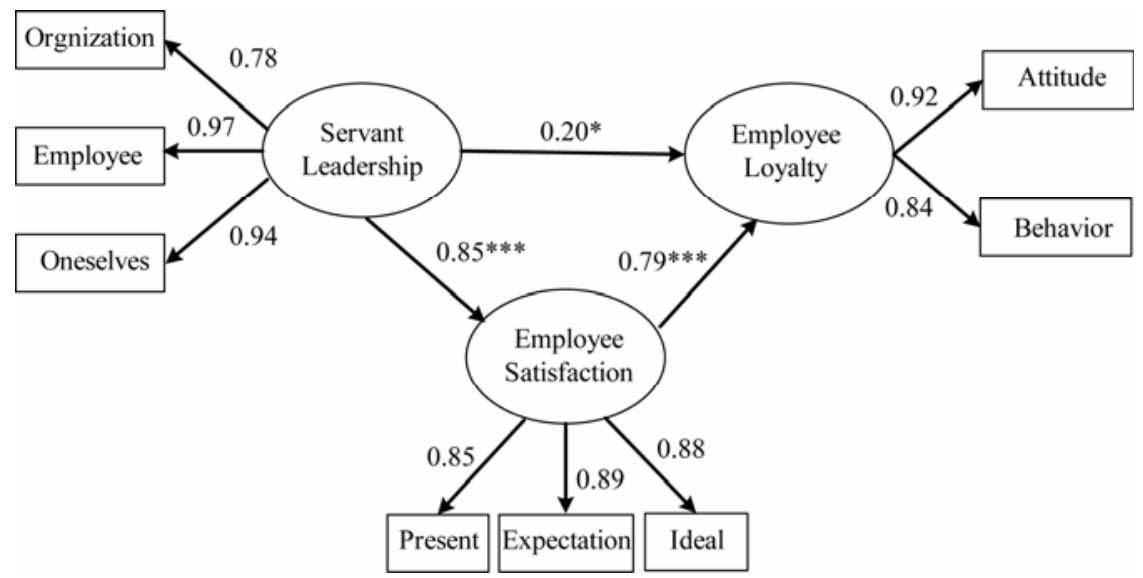

Figure 2. Complete standard solution of the structure model.

relationship of service-oriented leadership, employee satisfaction and employee loyalty, and we get the following points.

First of all, just as Jaramillo and other western scholars' research results, this paper's results show that there was significant positive correlation between the serviceoriented leadership behavior and employee loyalty. If the enterprise leader put servicing employees in the first place, achieving their development and success during the process of pursuing the goal of enterprise, bringing personal charm into full play in the management, drawing the outline of business blueprint for the employees, sincerely concerning about the staff of life needs, work demands, so that employees will form trust in team leader psychologically and improve their loyalty.

Secondly, just as Riketta and other western scholars' research ideas, this paper's results show that Employee satisfaction plays an intermediary role between serviceoriented leadership and employee loyalty, and data displays that its intermediary utility ratio reached $80 \%$. That is to say, the influence of service-oriented leadership on employee loyalty largely depends on this intermediary variable of employee satisfaction. Generally, people's attitude and behavior is mainly affected by the psychological experience and perceptual effects. Studying employee satisfaction as an intermediary variable also reflects the force of psychological motivation on their actions.

Scholars and practitioners have paid much attention to in identifying factors which cause employees to leave. A large number of studies have shown that when the employees engender dissatisfaction with the organization, there will be the intention to quit. Meanwhile, the studies show that the style of leadership plays a fundamental role in the assessment of the employees. The results of this study for management practice have certain significance, that the leader can improve the employee loyalty to their organization and reduce the brain drain according to the following two points.

First of all, the leaders should change the traditional idea. Instead of the top-down authoritarian style, the leaders must train a new service-oriented leadership style of their own, achieving organizational goals during the pursuit of the interests of employees. Leader can describe the feature vision of the organization to stimulate the employees' common fighting spirit, and through leadership charisma, using skills like respecting their personality, concerning about the life, word and future development of the employees, thus obtaining employees' recognition and trust, giving them autonomy, motivating them to achieve personal goals while fighting for the common goal of their organization.

Secondly, the leader of the enterprise should be good at creating a positive, harmonious atmosphere, giving employees a good satisfactory psychological experience. Bono [33] and other scholars pointed out that it would of great advantages to be fully aware of the importance of leadership style on the development of enterprises, because in such way leaders will create much less mental pressure, higher satisfaction with the positive work environment, and improve employee loyalty. According to Maslow's hierarchy needs theory, the demand of human being is a process from physiology, safety, social communication, to respect, and self-realization. Leaders should take these aspects into consideration and pay attention to the needs of employees step by step to raise their satisfaction to current job and organization. When the satisfaction of employee is improved, the psychological cost rises when it comes to departure, thus improving their dependence to the organization.

\section{Limitations and Future Research Directions}

Although the analysis of service-oriented leadership and 
employee satisfaction and the loyalty relationship has certain theoretical and practical significance, but also has the following limitations: firstly, the samples of this paper are mainly chosen from the MBA students of USTC (University of Science and Technology of China) and the employees of iFLYTEK, which may cause the limitation of both diversity and amount of the samples; secondly, since all three variables, the service-oriented leadership, employee satisfaction and employee loyalty, are from the same questionnaire answered by one person, common method variance may exist in the dataset we collected which can cause an expansion effect. Thirdly, we only use cross-sectional data in this paper so it doesn't mention anything about longitudinal analysis like whether the employee satisfaction and loyalty will reduce as the service-oriented leadership drops.

We will take an even deeper look at the following aspects for feature study: trying to make the samples' distribution more random, enlarging the amount of samples and increasing the response rate as possible as we can. Besides, we may analyze samples separately according to different regions and different industries in order to find whether there are differences between them. And we may also take more variables into consideration for feature study, such as organizational trust, psychological empowerment and so on.

\section{REFERENCES}

[1] T. N. Ingram, R. W. Laforge, W. B. Locander, S. B. Mackenzie and P. M. Podsakoff, "New Directions in Sales Leadership Research,” Journal of Personal Selling \& Sales Management, Vol. 25, No. 2, 2005, pp. 137-154.

[2] J. P. Mulki, F. Jaramillo and W. B. Locander, "Effects of Ethical Climate and Supervisory Trust on Salesperson's Job Attitudes and Intentions to Quit,” Journal of Personal Selling \& Sales Management, Vol. 26, No. 1, 2006, pp. 19-26.

[3] T. G. Brashear, D. N. Bellenger and J. S. Boles, “An Exploratory Study of the Relative Effectiveness of Different Types of Sales Force Mentors,” Journal of Personal Selling \& Sales Management, Vol. 26, No. 1, 2006, pp. 7-18. doi:10.2753/PSS0885-3134260101

[4] F. Jaramillo, D. B. Grisaffe, L. B. Chonko and J. A. Roberts, "Examining the Impact of Servant Leadership on Salesperson's Turnover Intention,” Journal of Personal Selling \& Sales Management, Vol. 29, No. 4, 2009, pp. 351-365. doi:10.2753/PSS0885-3134290404

[5] R. C. Liden, S. J. Wayne, H. Zhao and D. Herderson, "Servant Leadership: Development of a Multidimensional Measures and Multilevel Assessment," The Leadership Quarterly, Vol. 19, No. 2, 2008, pp. 161-177. doi:10.1016/j.leaqua.2008.01.006

[6] J. E. Barbuto Jr. and D. W. Wheeler, "Scale Development and Construct Clarification of Servant Leadership,"
Group and Organization Management, Vol. 31, No. 3, 2006, pp. 300-326. doi:10.1177/1059601106287091

[7] B. J. Avolio and W. L. Gardner, "Authentic Leadership Development: Getting to the Root of Positive Forms of Leadership,” Leadership Quarterly, Vol. 16, No. 3, 2005, pp. 315-338. doi:10.1016/j.leaqua.2005.03.001

[8] A. G. Stone, R. F. Russell and K. Patterson, "Transformational versus Servant Leadership: A Difference in Leader Focus," Leadership \& Organization Development Journal, Vol. 25, No. 4, 2004, pp. 349-361. doi:10.1108/01437730410538671

[9] S. Sendjaya, J. C. Sarros and J. C. Santora, "Defining and Measuring Servant Leadership Behaviour in Organizations," Journal of Management Studies, Vol. 45, No. 2, 2008, pp. 402-424.

[10] D. Van Dierendonck and I. Nuijten, “The Servant Leadership Survey: Development and Validation of a Multidimensional Measure,” Journal of Business and Psychology, Vol. 26, No. 3, 2011, pp. 249-267. doi:10.1007/s10869-010-9194-1

[11] C. X. Wang, Q. Ling and X. J. Zhang, "The Servant Leadership Scale Design and Inspection in Chinese Enterprise," Nankai Business Review, Vol. 3, 2009, pp. 94-103.

[12] D. W. Hart and J. A. Thompson, "Untangling Employee Loyalty: A Psychological Contract Perspective,” Business Ethics Quarterly, Vol. 17, No. 2, 2007, pp. 297-323. doi:10.5840/beq200717233

[13] R. Ilies and T. A. Judge, “An Experience Sampling Measure of Job Satisfaction: Its Relationships with Affectivity, Mood at Work, Job Beliefs, and General Job Satisfaction," European Journal of Work and Organizational Psychology, Vol. 13, No. 3, 2004, pp. 367-389. doi:10.1080/13594320444000137

[14] B. Mak and H. Sockel, "A Confirmatory Factor Analysis of IS Employee Motivation and Retention,” Information and Management, Vol. 38, No. 5, 2001, pp. 265-276. doi:10.1016/S0378-7206(00)00055-0

[15] M. H. E. Khalifa, "Perceptions of Equity and Job Satisfaction: A Study of University Employees in Egypt," International Journal of Management, Vol. 28, No. 4, 2011, pp. 130-144.

[16] M. L. Voon, M. C. Lo, K. S. Ngui and N. B. Ayob, “The Influence of Leadership Styles on Employee Job Satisfaction in Public Sector Organization Malaysia,” International Journal of Business, Vol. 2, No. 1, 2011, pp. 24-32.

[17] B. Shibru and G. M. Darshan, "Effects of Transformational Leadership on Subordinate Job Satisfaction in Leather Companies in Ethiopia,” International Journal of Business Management \& Economic Research, Vol. 2, No. 5, 2011, pp. 284-296.

[18] J. Y. Jiang, L.-Y. Sun and K. S. Law, “Job Satisfaction and Organization Structure as Moderators of the Effects of Empowerment on Organizational Citizenship Behavior: A Self-Consistency and Social Exchange Perspective," International Journal of Management, Vol. 28, No. 3, 2011, pp. 675-694.

[19] H. K. S. Laschinger, J. Finegan, J. Shamian and P. Wilk, 
"A Longitudinal Analysis of the Impact of Workplace Empowerment on Work Satisfaction," Journal of Organizational Behavior, Vol. 25, No. 4, 2004, pp. 527-545. doi:10.1002/job.256

[20] C. C. Chang, C. M. Chiu and C. A. Chen, "The Effect of TQM Practices on Employee Satisfaction and Loyalty in Government,” Total Quality Management, Vol. 21, No. 12, 2010, pp. 1299-1314. doi:10.1080/14783363.2010.530796

[21] J. Marjorie and A. C. Stewart, "Enhancing Nurse Job Satisfaction: The Importance of a Servant Leader Orientation in Health Care," Academy of Management Annual Meeting Proceedings, 2008, pp. 1-6.

[22] S. Mehta and R. Pillay, "Revisiting Servant Leadership: An Empirical Study in Indian Context," Contemporary Management Research, Vol. 5, No. 2, 2011, pp. 24-41.

[23] M. A. Jones, K. E. Reynolds and M. J. Arnold, "Hedonic and Utilitarian Shopping Value: Investigating Differential Effects on Retail Outcomes,” Journal of Business Research, Vol. 59, No. 9, 2006, pp. 974-981. doi:10.1016/j.jbusres.2006.03.006

[24] B. J. Babin, Y. K. Lee, E. J. Kim and M. Griffin, "Modeling Consumer Satisfaction and Word-of-Mouth: Restaurant Patronage in Korea," Journal of Services Marketing, Vol. 19, No. 3, 2005, pp. 133-139. doi:10.1108/08876040510596803

[25] T. Yao, W. B. Huang and X. C. Fan, "Research about Employee Loyalty of the Services Sector Based on the Organizational Commitment Mechanism," Management World Magazine, Vol. 5, 2008, pp. 102-123.

[26] S. Alfonso and S.-P. Andres, "The Effect of Job Satisfaction on Labor Turnover by Gender: An Analysis for Switzerland," Journal of Socioeconomics, Vol. 3, No. 6, 2007, pp. 859-913.
[27] C. Chee, K. Haddad and G. Singh, "Human Resources Management, Job Satisfaction, Morale, Optimism and Turnover," International Journal of Hospitality and Tourism Administration, Vol. 8, No. 2, 2007, pp. 73-88. doi:10.1300/J149v08n02_04

[28] K. Falkenburg and B. Schyns, "Work Satisfaction, Organizational Commitment and Withdrawal Behaviors," Management Research News, Vol. 30, No. 10, 2007, pp. 708-723. doi:10.1108/01409170710823430

[29] C. M. Wagner, “Organizational Commitment as a Predictor Variable in Nursing Turnover Research: Literature Review," Journal of Advanced Nursing, Vol. 60, No. 3, 2007, pp. 235-247. doi:10.1111/j.1365-2648.2007.04421.x

[30] T. A. Wright and D. G. Bonett, "Job Satisfaction and Psychological Well-Being as Non-Additive Predictors of Workplace Turnover,” Journal of Management, Vol. 33, No. 2, 2007, pp. 141-160. doi:10.1177/0149206306297582

[31] M. Riketta and R. Van Dick, "Foci of Attachment in Organizations: A Meta-Analytic Comparison of the Strength and Correlates of Workgroup versus Organizational Identification and Commitment," Journal of Vocational Behaviour, Vol. 67, No. 3, 2005, pp. 490-510. doi:10.1016/j.jvb.2004.06.001

[32] M. F. Y. Cheung and W.-P. Wu, "Leader-Member Exchange and Employee Work Outcomes in Chinese Firms: The Mediating Role of Job Satisfaction,” Asia Pacific Business Review, Vol. 18, No. 1, 2012, pp. 65-81. doi:10.1080/13602381.2010.535346

[33] J. E. Bono, H. J. Foldes, G. Vinson and H. P. Muros, "Workplace Emotions: The Role of Supervision and Leadership,” Journal of Applied Psychology, Vol. 92, No. 5, 2007, pp. 1357-1367. doi:10.1037/0021-9010.92.5.1357 